\title{
Population Sciences
}

National Cancer Institute

\section{Source}

National Cancer Institute. Population Sciences. NCI Thesaurus. Code C19491.

As defined by various Divisions within the $\mathrm{NCl}$ they include: Epidemiology, Nutrition,

Behavioral Medicine, Genetics, Public Health, Anthropology, Tobacco Control Research,

Demography, Bioethics, Sociology. 